\title{
OTONOMI DESA DAN KESEJAHTERAAN MASYARAKAT NEGERI BATU MERAH PASCA UNDANG-UNDANG NOMOR 6 TAHUN 2014 TENTANG DESA (PERSPEKTIF HUKUM PROGRESIF)
}

\author{
Ahmad Lonthor \\ Fakultas Syariah dan Ekonomi Islam IAIN Ambon \\ Email: lonthora@gmail.com
}

\begin{abstract}
ABSTRAK
Pandangan hukum progresif terhadap otonomi desa dan kesejahteraan masyarakat negeri Batu Merah dalam kedudukan undang-undang nomor 6 tahun 2014 tentang desa jika dikorelasikan maka cenderung mengedepankan cita-cita hukum untuk manusia, maka relevansi animo masyarakat negeri Batu Merah yang menginginkan kemandirian dalam mengurusi otonomi desa mereka sendiri sebagaimana yang telah di amanahkan oleh undang-undang pada prinsipnya menggunakan pendekatan hukum progresif adalah sejalan dengan cita budaya hukum indonenesia yang menekankan nilai-nilai yang hidup di dalam masyarakat. Kata Kunci: otonomi desa, kesejahteraan masyarakat, hukum progresif
\end{abstract}

\begin{abstract}
Progressive jurisdictional view to silvan autonomy and well-being country society petrifies statute position deep red number 6 years 2014 about villages if dikorelasikan therefore tend advance law aspiration for human, therefore relevansi country society energy Batu Merah who want independence in mengurusi their own village autonomy as it were have already at amanahkan by law thus principally utilize progressive law approaching is in line with culture goal sentence indonenesia who emphasizes to assess - the living one point in society.

Key word: silvan autonomy, society welfare, progressive law
\end{abstract}

\section{Pendahuluan}

Dalam mencemati proses pencapaian keadilan dalam sistem penyelenggaraan berkehidupan di bidang ekonomi, politik, sosio kultural, dan penegakan hukum, maupun pengharapan terhadap hak asasi manusia merupkana gambaran sebuah dinamika dari bangsa Indonesia dalam menjawab tantangan perubahan zaman dan memberikan visi dalam upaya menciptakan masa depan yang lebih baik bagi kehidupan berbangsa dan bernegara dalam bingkai demokrasi. ${ }^{1}$

Aritoteles menyatakan bahwa demokrasi mempunyai makna negatif dalam perkembangannya demokrasi justru mempunyai makna positif, makna demokrasi negatif dikemukakan oleh Aritoteles pada waktu pakar filsafat tersebut mengemukakan perkembangan tipe-tipe pemerintahan. Diawali dengan landasan tipe-tipe pemerintahan

\footnotetext{
${ }^{1}$ H. Soehino, Hukum Tata Negara, Sejara Ketatanegaraan Indonesia Menjelang Dan Pasca Di Lakukan Perubahan Pertama, Perubahan Kedua, Perubahan ketiga Dan Prubahan Keempat UndangUndang Dasar Negara Republik Indonesia Tahun 1945, (ed.2005-2006, Yogyakarta,BPFE, 2005), h. 19
} 


\section{Tahkím}

Vol. XIV, No. 1, Juni 2018

atas bentuk yang baik dan bentuk yang buruk serta dihubungkan dengan pemerintahan oleh satu orang, beberapa orang dan banyak orang. Dengan demikian demokrasi tidak dapat dibayangkan tanpa adanya kebebasan dan persamaan. Ini berarti bahwa kebebasan dan persamaan merupakan landasan berpijak demokrasi. Tanpa kebebasan dan persamaan tidak mungkin ada demokrasi. Hal itu tercermin dari diakuinya antara lain kebebasan berpendapat, kebebasan berorganisasi, kebebasan beragama, serta adanya persamaan kedudukan di depan hukum dalam konteks ketatanegaraan. ${ }^{2} \mathrm{Hal}$ itu untuk Indonesia diamanahkan dalam alenia keempat Pembukaan UUD NRI Tahun 1945 yaitu melindungi segenap dan seluruh tumpah darah Indonesia.

Keberlakukan sistem desentralisasi pasca reformasi $1998,{ }^{3}$ melalui otonomi daerah dalam perkembangannya memunculkan persoalan baru. Kewenangan yang diberikan kepada pemerintah daerah untuk mengembangkan ekonomi dan mengelola sumber daya alam, justru melahirkan raja-raja kecil di daerah. Akibatnya, desentralisasi yang diharapkan bisa mensejahterakan masyarakat justru menghasilkan sesuatu yang kontaproduktif. Kesenjangan ekonomi terus melebar. Hal ini ditunjukan dengan rasio kini dari tahun pertahun yang terus meningkat. Data BPS 2013 menunjukan bahwa pada 1999, indeks gini Indonesia tercatat sebesar 30,8 dan kemudian melonjat ke 41,3 pada $2013 .{ }^{4}$

Upaya untuk mensejahterakan masyarakat desa tidak lari dari upaya pemberdayaan masyarakat yang berbasis kelembagaan lokal, peran sumber manusia yang mampu serta profesional dapat dijadikan refleksi pada situasi dan keinginan. Menumbuhkembangkan nilai-nilai kesetiakawanan, kebersamaan, hidup saling tolong menolong sebagai modal masyarakat untuk menggerakan masyarakat miskin, menemukan potensi-potensi lokal untuk dikelola sebagai sumber energy bersama. Wujud partisipasi tersebut, dan masyarakat merupakan elemen kunci setiap unsur dan sistem program pemerintah dalam mengimplementasikan Undang-Undang Nomor 6 Tahun 2014 tentang Desa. ${ }^{5}$ Kewenangan yang di berikan dalam Undang-Undang Desa sebagaimana tertuang dalam BAB IV Pasal 18 yaitu kewenangan desa meliputi kewenangan di bidang penyelenggara pemerintah desa, pelaksanaan pembangunan desa, pembinaan kemasyarakatan desa, dan pemberdayaan masyarakat desa berdasarkan prakarsa masyarakat, hak asal usul, dan adat isti adat. ${ }^{6}$

\footnotetext{
${ }^{2}$ HRT.SriSoemantri, Hukum Tatanegara Indonesia Pemikiran Dan Pandangan, (Cet I,Bandung, PT Remaja Rosdakarya, 2014), h.49-50

${ }^{3}$ Karel Albert Ralahalu, Otonomi Daerah di Tengah Konflik Merancang Succes Story Implementasi Otonomi Daerah Di Provinsi Maluku dalam Suatu Pengantar Menteri Dalam Negeri H. Moh. Ma'ruf, Cet II, 2012, h, 11

${ }^{4}$ Didik Sukriono, M. Syaiful Aris, Umbu Pariangu, Otonomi Desa Dan Kesejatraan Rakyat, (Malang: Intras Institute, 2014), h, 1.

${ }^{5}$ Ibid.

${ }^{6}$ Lihat ketentuan pasal 18 Undang Undang Nomor 6 Tahun 2014 Tentang Desa
} 


\section{Tahkím}

Vol. XIV, No. 1, Juni 2018

Oleh karena itu masalah otonomi desa yang dicita-citakan menjadi sesuatu yang baru dalam sistem ketatanegaraan agar desa mampu mengurusi rumah tangganya sendiri. Hal ini dapat dilihat pada otonomi desa di Desa Batu Merah Kecamatan Sirimau Kota Ambon dalam sistem pemerintahannya yang berusaha untuk memprioritaskan masyarakatnya baik dalam pemberdayaan maupun pembangunan sebelum dan sesudah di undangkannya Undang-Undang Nomor 6 Tahun 2014 tentang Desa. Kucuran dana desa yang berasal dari APBN dan APBD merupakan respon positif oleh pemerintah desa maupun masyarakat untuk mewujudkan kesejahteraan mereka di berbagai aspek kehidupan.

\section{Kerangka Teori}

\section{Teori Hukum Progresif}

Hukum progresif lahir sebagai respon atas kualitas penegakan hukum di Indonesia yang lebih cenderung kaku, formal, dan tidak berkeadilan sosial, sekaligus menjawab kegagalan penerapan analitycal jurisprudence, Hukum Progresif memiliki asumsi dasar hubungan antara hukum dengan manusia. Progresivisme bertolak dari pandangan kemanusiaan bahwa manusia pada dasarnya adalah baik, memiliki sifat-sifat kasih sayang serta kepedulian terhadap sesama. Dengan demikian asumsi dasar hukum progresif di mulai dari hakikat dasar hukum adalah untuk manusia. Hukum tidak hadir untuk dirinya sendiri sebagimana yang digagas oleh ilmu hukum positif, tetapi untuk manusia dalam rangka mencapai kesejahteraan dan kebahagiaan manusia. Posisi yang demikian mengantarkan satu predisposisi bahwa hukum itu selalu berada pada status 'law in the making' (hukum yang selalu berproses). ${ }^{7}$

Gagasan yang demikian ini jelas berbeda dengan aliran hukum positif yang menggunakan sarana analitycal jurisprudence yang bertolak dari premis peraturan dan logika. Bagi ilmu hukum positif (dogmatic), kebenaran terletak pada tubuh peraturan. Ini yang dikritik oleh hukum progresif, karena hukum yang hanya berupa pasal-pasal jelas tidak bisa menggambarkan kebenaran dari hukum yang sangat kompleks dari realitas-empirik jelas sangat diragukan posisinya sebagai ilmu hukum yang benar ilmu (genuine science). Hukum progresif secara sadar menempatkan kehadirannya dalam hubungan erat dengan manusia dan masyarakat, dalam posisi yang demikian ini, maka hukum progresif dapat dikaitkan dengan developmetal model hukum dari Nonet dan Selznick. ${ }^{8}$

Nonet dan Selznick lewat hukum responsif, menempatkan hukum sebagai sarana respons terhadap ketentuan-ketentuan sosial dan aspirasi publik. Sesuai dengan sifatnya yang terbuka, maka tipe hukum ini mengedepankan akomodasi untuk menerima perubahan-perubahan sosial demi mencapai keadilan dan emansipasi publik.

\footnotetext{
${ }^{7}$ Hasanuddin, op. cit. h. 20-21

${ }^{8}$ Ibid.
} 


\section{Tahkím}

Vol. XIV, No. 1, Juni 2018

Kepedulian kepada akomodasi aspirasi sosial, mengakibatkan teori ini tergolong dalam wilayah sociological jurisprudence. Bahkan menurut Noet-Selznick, hukum responsif merupakan program dari sociological jurisprudence dan realist jurisprudence. Dua aliran tersebut pada intinya menyerukan kajian hukum yang lebih empirik melampui batas-batas formalism, perluasan pengetahuan hukum, dan peran kebijakan dalam putusan hukum. ${ }^{9}$

Kemudian pandangan yang cukum menarik di kembangkan oleh hukum yang berpresfektif sosiologis, salah satu tokohnya adalah Rescoe Pound. Pound yang terkenal dengan mengajarkan bahwa law as a tool of social engineering (hukum sebagai alat perubahan sosial). Atas tanggapan bahwa hukum sebagai alat perubahan sosial, maka hukum harus berorientasi ke masa depan, bukan berorientasi ke masa lampau. Hukum pada akhirnya harus berperan aktif guna menimbulkan pembaruan dalam masyarakat, sehingga fungsi hukum tidak hanya untuk menciptakan ketertiban, tetapi justru mendorong perubahan dalam masyarakat. ${ }^{10}$

Menurut Rahardjo, pemikiran hukum perlu kembali pada filosofi dasarnya, yaitu hukum untuk manusia. Dengan filosofi tersebut, maka msnusia menjadi penentu dan titik orientasi hukum. Hukum bertugas melatani manusia, bukan sebaliknya. Oleh karena itu, hukum itu bukan merupakan institusi yang lepas dari kepentingan manusia. Mutu hukum, di tentukan oleh kemampuannya untu mengabdi pada kesejahteraan manusia. Ini menyebabkan hukum progresif menganut "ideologi" hukum yang prokeadilan dan hukum yang pro-rakyat. Dengan ideologi ini di dedikasi para pelaku hukum mendapat tempat yang utama untuk melakukan pemulihan. Para pelaku hukum di tuntut mengedepankan kejujuran dan ketulusan dalam penegakan hukum. Mereka harus memiliki empati dan kepedulian pada penderitaan yang dialami rakyat dan bangsa ini. Kepentingan rakyat (kesejahteraan dan kebahagiaannya), harus menjadi titik orientasi dan tujuan akhir penyelenggaraan hukum. ${ }^{11}$

\section{Teori Sistem Hukum}

Teori Legal System dari L. Friedman, bahwa sistem hukum merupakan suatu sistem yang meliputi substansi, struktur dan budaya hukum. Unsur pertama, Legal structure atau Struktur hukum merupakan institusionalisasi ke dalam entitas-entitas hukum, seperti struktur pengadilan, tingkat pertama, pengadilan tingkat banding dan pengadilan tingkat kasasi, jumlah hakim serta integrated justice system, Friedman menegaskan bahwa hukum memiliki elemen pertama dari sistem hukum adalah struktur hukum, tatanan kelembagaan, dan kinerja lembaga. Unsur kedua adalah substansi

\footnotetext{
${ }^{9}$ Bernard L. Tanya, Yoan N. Simanjuntak, Markus Y. Hage, Teori Hukum Strategi Tertib Manusia Lintas Ruang Dan Generasi, (Surabaya: Genta Publishing, 2006), h. 184-185

${ }^{10}$ Mahmud Kusuma, Menyelami Semangat Hukum Progresif, Terapi Paradigmatik Bagi Lemahnya Penegakan Hukum Indonesia, (Yogyakarta: Antony Lib-Indonesia, 2009), h. 103

${ }^{11}$ Ibid., h. 190
} 


\section{Tahkím}

Vol. XIV, No. 1, Juni 2018

hukum merupakan aturan, norma hukum dan pola perilaku manusia yang berada dalam sistem itu. Menurut Friedman pengertian substansi tidak hanya terbatas pada persoalan hukum yang tertulis law books, tetapi juga termasuk living law atau hukum yang berlaku dan hidup dalam masyarakat. Unsur ketiga adalah budaya hukum (legal culture) yaitu sikap-sikap dan nilai-nilai yang berhubungan dengan hukum bersamasama dengan sikap-sikap dan nilai-nilai yang terkait dengan tingka laku yang berhubungan dengan hukum dan lembaga-lembaganya, baik secara positif maupun negatif. $^{12}$

\section{Metode Penelitian}

Jenis penelitian yang digunakan pada penelitian ini adalah penelitian hukum empiris (penelitian yuridis sosiologi) yaitu penelitian yang menitikberatkan pada masyarakat dalam kaitanya dengan otonomi desa maupun kesejahteraan dan hukum. ${ }^{13}$ Penelitian di laksanakan di desa Batu Merah. Penelitiah yuridis sosiologis untuk meneliti bekerjanya hukum di dalam masyarakat, mengamati apa yang menjadi karakater sebuah perilaku masyarakat di suatu wilayah dalam suatu aspek kehidupan. ${ }^{14}$ Pendekatan yang digunakan dalam penelitian ini adalah pendekatan konseptual dan pendekatan perundang-undangan yaitu peraturan perundang-undangan dan konsepkonsep dalam ilmu hukum dijadikan titik tolak atau pendekatan bagi analisis hukum. Proses pengumpulan data, digunakan studi lapangan dan studi kepustakaan. Data dianalisis secara deskriptif kualitatif.

\section{Upaya Pemerintah Negeri dalam Memberdayakan Masyarakat Negeri Batu Merah}

Salah satu peranan lembaga kemasyarakatan adalah membantu tugas-tugas kemanusiaan seperti pemberdayaan perempuan, penguatan kapasitas sumberdaya manusia maupun tugas-tugas lainnya tidak dapat di abaikan begitu. Meskipun ditemui belum seluruhnya lembaga kemasyarakatan yang ada di masyarakat negeri Batu Merah telah meaksanakan fungsinya karena berhubungan dengan struktur kelembagaannya. Lembaga-lembaga kemasyarakatan antara lain (1) TP PKK, Dasawisma; (2) organisasi pemuda; (3) kelompok tani; (4) kelompok pengrajin kulit kerang; (5) lembaga saniri negeri; dan (6) lembaga keagamaan dan sebagainya. ${ }^{15}$

Langkah yang ingin dicapai dari pemberdayaan masyarakat oleh pemerintah negeri Batu Merah adalah untuk membentuk individu dan masyarakat menjadi mandiri. Kemandirian tersebut meliputi kemandirian berfikir, bertindak, dan mengendalikan apa

\footnotetext{
${ }^{12}$ Achmad Ali, Menguak Teori Hukum Dan Teori Peradilan (Jakarta: Kencana, 2009), h. 204

${ }^{13}$ Suratman, dkk. Metode Penelitian Hukum, (Bandung: Alfabeta, 2013), h. 88.

${ }^{14}$ Mukti Fajar, Dualisme Penelitian Hukum Normatif dan Empiris, (Yogyakarta: Pustaka Pelajar, 2010), h.53-56.

${ }^{15}$ Ida Leurima, Sekretaris Pengurus Pemerintahan Desa/Negeri di Negeri Batu Merah Kecamatan Sirimau Kota Ambon, Tanggal 25 Agustus 2016
} 


\section{Tahkím}

Vol. XIV, No. 1, Juni 2018

yang mereka lakukan. sehingga tujuan pemberdayaan masyarakat negeri Batu Merah adalah memampukan dan memandirikan masyarakat terutama dari kemiskinan, keterbelakangan, kesenjangan, dan ketidakberdayaan. Kemiskinan dapat dilihat dari indikator pemenuhan kebutuhan dasar yang belum mencukupi. ${ }^{16}$

Peran pemerintah negeri Batu Merah dalam memberikan kesejahteraan merupakan tugas utama. Untuk itu sudah selayaknya anggaran negara di alokasikan untuk kesejahteraan rakyat. Berbagai model pemberdayaan masyarakat, tidak luput dari peran pemerintah negeri dalam memberdayakan masyarakat. Banyak program pemberdayaan masyarakat yang digulirkan pemerintah melalui Departemen maupun Lembaga Pemerintah Non Departemen seperti PNPM Mandiri (Program Nasional Pemberdayaan Masyarakat) PNPM adalah program nasional Untuk itu, melalui Program Nasional Pemberdayaan Masyarakat (PNPM) Mandiri diharapkan dapat terjadi harmonisasi prinsip-prinsip dasar, pendekatan, strategi, serta berbagai mekanisme dan prosedur pembangunan berbasis pemberdayaan masyarakat sehingga proses peningkatan kesejahteraan masyarakat dapat berjalan lebih efektif dan efisien. ${ }^{17}$

Salah satu potensi di negeri Batu Merah dalam memberikan gambaran umum mengenai kondisi pertanian di negeri Batu Merah mencakup subyektor tanaman pangan, holtikultira, perkebunan, peternakan, perikananan dan kehutanan termasuk jasa pertanian. Dalam presentase rumah tangga usaha pertanian menurut desa/kelurahan di kecamatan Sirimau antara lain adalah sebagai berikut ${ }^{18}$ :

\begin{tabular}{|l|l|l|}
\hline No & \multicolumn{1}{|c|}{ Desa/Negeri/Keluarahan } & \multicolumn{1}{|c|}{ Presentase hasil pertanian } \\
\hline 1 & Galala & $1.04 \%$ \\
\hline 2 & Hative Kecil & $14.04 \%$ \\
\hline 3 & Pandan Kasturi & $4.84 \%$ \\
\hline 4 & Batu Merah & $50.57 \%$ \\
\hline 5 & Kel. Amantelu & $0.38 \%$ \\
\hline 6 & Kel. Rijali & $1.33 \%$ \\
\hline 7 & Kel. Uritetu & $0.28 \%$ \\
\hline 8 & Kel Hunipopu & $0.19 \%$ \\
\hline 9 & Kel. Ahusen & $0.00 \%$ \\
\hline 10 & Kel. Batu Gaja & $1.90 \%$ \\
\hline 11 & Kel. Batu Meja & $2.09 \%$ \\
\hline 12 & Kel. Karang Panjang & $0.66 \%$ \\
\hline 13 & Kel.Tanah Tinggi & $3.04 \%$ \\
\hline 14 & Soya & $19.4 \%$ \\
\hline
\end{tabular}

\footnotetext{
${ }^{16}$ M. Saleh Kiat, Pejabat Negeri Batu Merah "wawancara", di Kantor Pemerintah Negeri Batu Merah pada tanggal 20 juli, 2016.

${ }^{17}$ Ibid.

${ }^{18}$ Badan Pusat Statistik Kota Ambon, Potret Usaha Pertanian Hasil Sensus Pertanian Desa Batu Merah Tahun 2016
} 


\section{Tahkím}

Vol. XIV, No. 1, Juni 2018

Kemudian jumlah rumah tangga usaha pertanian desa Batu Merah kecamatan Sirimau Kota Ambon menurut subsektor (rumah tangga) adalah:

\begin{tabular}{|l|l|l|}
\hline No & \multicolumn{1}{|c|}{ Subsektor (Rumah Tangga) } & \multicolumn{1}{c|}{ Skor } \\
\hline 1 & Jasa pertanian & $10 \%$ \\
\hline 2 & Perkebunan & $64 \%$ \\
\hline 3 & Holtikultura & $126 \%$ \\
\hline 4 & Tanaman Pangan & $163 \%$ \\
\hline 5 & Perikanan & $12 \%$ \\
\hline 6 & Peternakan & $374 \%$ \\
\hline 7 & Kehutanan & $18 \%$ \\
\hline
\end{tabular}

Tabel lima komoditas unggulan desa Batu Merah

\begin{tabular}{|l|l|l|}
\hline No & \multicolumn{1}{|c|}{ Komoditas Unggulan } & \multicolumn{1}{c|}{ Skor } \\
\hline 1 & Ayam lokal & 384 rumah tangga \\
\hline 2 & Ubi kayu & 154 rumah tangga \\
\hline 3 & Pisang & 64 rumah tangga \\
\hline 4 & Nenas & 50 rumah tangga \\
\hline 5 & Cengkeh & 43 rumah tangga \\
\hline
\end{tabular}

Bertolak dari realita dan perkembangan masyarakat, kondisi dan masalah terkini yang berkembang dalam masyarakat negeri Batu Merah, serta tantangan dan harapan yang ingin diwujudkan lima tahun kedepan, telah ditetapkan visi RPJM-N Batu Merah tahun 2015-2020 yakni Terciptanya Kerja Sama Yang Baik Antara Aparatur Desa/Negeri Dan Terwujudnya Pelayanan Prima Kepada Masyarakat Yang Di Dukung Tertib Administrasi Dengan Suasana Aman dan Religius. ${ }^{19}$

Dalam konteks pembangunan masyarakat, maka visi pembangunan jangka menengah negeri (RPJM-N) Batu Merah tidak dapat dilepaspisahkan dari visi pembsngunan daerah kota ambon. Olehnya itu, visi ini dapat di maknai seluruh struktur kehidupan masyarakat negeri Batu Merah yang bertolak dari kondisi saat ini dan harapan kedepan. Atas pertimbangan tersebut sehingga visi RPJM negeri Batu Merah memiliki empat makna penting, yakni:

Kerjasama yang baik. Pernyataan ini bermakna supaya dapat meningkatkan atau membangkitkan semangat untuk melakukan kerja sama yang baik antara aparatur negeri dengan masyarakat dalam memberikan pelayanan dalam bentuk apapun. Sehingga dapa bernilai dan bermanfaat bagi kelangsungan hidup masyarakat negeri Batu Merah, sehingga masyarakat dapat bangun dari keterpurukan yang selama ini masih dirasakan dalam kehidupan bermasyarakat. Agar segala yang menjadi kendala

\footnotetext{
${ }^{19}$ Rancangan Pembangunan Jangka Menengah (RPJMDes Dan REKPDES) Negeri Batu Merah Kecamatan Sirimau Kota Ambon Tahun 2015-2020
} 


\section{Tahkim}

Vol. XIV, No. 1, Juni 2018

dalam proses peningkatan taraf hidup masyarakat dapat ditingkan menjadi suatu masyarakat yang memang betul-betul dapat di katakana sebagai masyarakat yang maju.

Pelayanan Prima. Pernyataan ini bermakna agar bagaimana memanfaatkan kekuatan potensi sumber daya manusia yang unggul di masyarakat baik sumber daya alam maupun sumber daya manusia sehingga aparatur negeri dapat berperan serta dalam memmberikan pelayanan yang prima untuk memperbaiki dan meningkatkan kehidupan sosial ekonomi masyarakat.

Tertib Administrasi. Pernyataan ini bermakna agar dengan meningkatkan kesempurnaan dalam proses perbaikan administrsi kependudukan yang selama ini di nilai masih amburadul sehingga administrasi yang baik dan benar.

Aman dan religius. Pernyataan ini bermakna agar dalam menjalani kehidupan bermasyarakat di negeri Batu Merah selalu dalam kondisi yang aman, tentram, damai, serta terciptanya masyarakat yang religius, serta tidak adanya saling permusuhan atar warga antar warga dengan perangkat pemerintan negeri sekalipun, sehingga seluruh proses kemasyarakatan dapat dengan baik.

Misi Negeri Batu Merah Untuk mewujudkan visi di atas. Misi Negeri Batu Merah yang selanjutnya dijabarkan ke dalam kebijakan program dan kegiatan, yakni: ${ }^{20}$

a. meningkatkan kerja sama dan disiplin aparatur Pemerintah Negeri

b. Menyelenggarakan kegiatan tertib administrasi pemerintah dan Negeri

c. Menggali dan memanfaatkan sumber daya alam dan potensi Negeri untuk kepentingan masyarakat.

d. Membangun dan mendorong majunya bidang pendidikan baik formal atau non formal serta pendidikan agama yang mudah dan murah

e. Meningkatkan kerukunan hidup antara umat beragama.

Misi adalah upaya yang dilakukan untuk mendorong percepatan pencapaian harapan atau visi RPJM Negeri Batu Merah. Dalam hubungan dengan itu, misi memiliki variabel-variebel terukur yang selanjutnya yang dijabarkan dalam arah kebijakan penglokasian program lima tahunan. ${ }^{21}$

Untuk mewujudkan visi dan misi Pemerintah Batu Merah, pada hakekatnya perlu diintervensi dengan program dan kegiatan prioritas baik yang menjadi Kewenangan Negeri Batu Merah maupun yang memerlukan dukungan Pemerintah Daerah Kota Ambon melalui Satuan Kerja Perangkat Daerah, termaksud dukungan sector swsta. Olehnya itu, RPJM-NEG Batu Merah memiliki kandungan yang sangat strategi yang sanagat, karena telah merumuskan langkah-langkah kebijakan prioritas yang dijabarkan melalui program dan kegiatan alokasi pagu indikatif.

Rencana pembangunan jangka menengah negeri (RPJM-N) Batu Merah tahun 2015-2020 merupakan cermin tekad dan komitmen pemerintah negeri Batu Merah bersama masyarakat untuk memberikan pengabdian terbaik bagi kemajuan dan

${ }^{20}$ Ibid
${ }^{21}$ Ibid 


\section{Tahkím}

Vol. XIV, No. 1, Juni 2018

pengembangan negeri Batu Merah. Pada tataran operasional, rencana pembangunan jangka menengah berfungsi sebagai acuan dasar dalam prowess identifikasi dan perumusan program kerja yang terimpelementasin ke dalam kegiatan-kegiatan pokok dengan melibatkan instansi terkait, masyarakat maupun sektor swasta.

Melalui fungsi utama rencana pembangunan jangka menengah, programprogram yang disusun dan disepakati akan disinkronkan dengan kebijakan pembangunan daerah Kota Ambon melalui dukungan dan peran satuan kerja perangkat daerah (SKPD) dalam koridor koordinasi sehingga diharapkan dapat mnenghasilkan program-program yang berkualitas agar mampu memberikan kontribusi bagi pencapaian visi dan misi pemerintah kota Ambon, pembangunan daerah provinsi Maluku, dan pembangunan nasional.

Keberhasilan pelaksanaan rencana pembangunan jangka menengah negeri Batu Merah sangat tergantung pada sikap dan mental, tekad, semangat dan disiplin para penyelenggara pemerintah di pemerintahan Kota Ambon, kecamatan sirimau, negeri Batu Merah dengan dukungan peran serta masyarakat secara luas. Dalam kaitan dengan itu, pemerintah negeri Batu Merah bersama-sama masyarakat perlu bersungguhsungguh melaksanakan berbagai kebijakan program pembangun yang di rumuskan agar mampu memberikan hasil yang dapat dinikmati secara lebih adil dan merata oleh seluruh masyarakat di negeri Batu Merah dengan cita-cita luhur dan harapan masa depan yakni "terciptanya kerja sama yang baik antara aparatur desa/ negeri dan terwujudnya pelayanan prima kepada masyarakat yang di dukung tertib administrasi dengan suasana aman dan relegius."

Berdasarkan analisa kuantitas program kerja pemerintah negeri Batu Merah dalam mengelola otonomi desanya sendiri tersebut, interprestasi terhadap tingkat pemerataan kesejahteraan masyarakat dapat dibagi berdasarkan kapasitas ekonomi, pendidikan, dan kuantitas materi. Dalam hal ini Yuliantoro dan Damayanti mengemukakan, bahwa indikator pengukuran kesejahteraan untuk wilayah Indonesia, secara umum didasarkan atas kapasitas ekonomi, pendidikan dan kuantitas materi atau gaya hidup yang berlaku pada suatu masyarakat, hal ini didasarkan paradigma masyarakat Indonesia yang menjadikan pendidikan dan gaya hidup sebagai salah satu tolak ukur kesejahteraan. ${ }^{22}$ Dengan demikian interprestasi kesejahteraan terhadap masyarakat negeri Batu Merah juga didasarkan atas paradigma pendidikan sehingga mampu melakukan apa yang di amanahkan oleh undang-undang nomor tahun 2014 tentang desa.

Tingkat kesejahteraan tersebut dapat dikomparasikan menurut responden penelitian yang terbagi atas Raja/kepala pemeritahan, sekretaris, saniri negeri maupun masyarakat negeri Batu Merah bahwa Interprestasi analisis terhadap para responden

\footnotetext{
${ }^{22}$ Yuliantoro \& M. Damayanti, "Is Economic Viability The Answer For Community's E American Qol Assessment,?” Jurnal Tataloka, Vol. 10, No. 1, 2008, h. 37-48.
} 


\section{Tahkím}

Vol. XIV, No. 1, Juni 2018

menunjukan bahwa otonomi desa dalam mengelola sumberdaya di negeri Batu Merah terhadap pemerataan dan kesejahteraan masyarakat dilihat dari tingkat kapasitas ekonomi/pemerataan terhadap dana desa dalam sistem pembangunan dan pemberdayaan bagi masyarakat sudah menyentuh dalam pemerintahan yang ada di negeri Batu Merah.

Penyelenggaraan pemerintahan di negeri Batu Merah dalam melakukan interprestasi Undang-Undang Nomor 6 Tahun 2014 tentang Desa memang saat ini sangat diharapkan oleh masyarakat. Sehingga desakan masyarakat untuk pemerintah negeri dalam melakukan suatu bentuk kepastian hukum untuk bagaimana menata sumberdaya alam yang ada di negeri Batu Merah untuk dijadikan sebagai pendapatan negeri melalui peraturan-peraturan negeri terhadap permasalahan yang ada di negeri Batu Merah itu sendiri.

\section{Korelasi Hukum Progresif Terhadap Otonomi Desa}

Menurut Satjipto Rahardjo bahwa hukum adalah untuk manusia, dan bukan sebaliknya, lebih tepatnya dikatakan bahwa Hukum itu bukan hanya bangunan peraturan, melainkan juga bangunan ide, kultur, dan cita-cita. ${ }^{23}$

Dalam logika itulah revitalisasi hukum dilakukan setiap kali. Bagi hukum progresif, proses perubahan tidak lagi berpusat pada peraturan, tetapi pada kreativitas pelaku hukum dalam mengaktualisasikan hukum pada ruang dan waktu yang tepat. Para pelaku hukum progresif dapat melakukan perubahan dengan melakukan pemaknaan yang kreatif terhadap peraturan yang ada, tanpa harus menunggu perubahan peraturan (changing the law). Peraturan buruk tidak harus menjadi penghalang bagi para pelaku hukum progresif untuk menghadikarkan keadilan untuk rakyat dan pencari keadilan, karena mereka dapat melakukan interprestasi secara baru setiap kali terhadap suatu peraturan. Untuk itu agar hukum dirasakan manfaatnya, maka dibutuhkan jasa pelaku hukum yang kreatif menterjemahkan hukum itu dalam kepentingan-kepentingan sosial yang memang harus dilayaninya. ${ }^{24}$

Berdasarkan teori ini keadilan tidak bisa secara langsung ditemukan lewat proses logis formal. Keadilan justru diperoleh lewat institusi, karenanya, argumentargumen logis formal "dicari" sesudah keadilan ditemukan untuk membingkai secara yuridis-formal keputusan yang diyakini adil tersebut. Oleh karena itu konsep hukum progresif, hukum tidak mengabdi bagi dirinya sendiri, melainkan untuk tujuan yang berada di luar dirinya.

${ }^{23}$ Zain Al-Muhtar, Teori Hukum Progresif Menurut Satjipto Rahardjo, dalam http://sergiezainovsky.blogspot.com/2012/10/teori-hukum-progresif-menurut-satjipto.html,h. 2 diakses pada Mei 2018

${ }^{24}$ Bernard L. Tanya, Yoan N. Simanjuntak, Markus Y. Hage, Teori Hukum Strategi Tertib Manusia Lintas Ruang Dan Generasi, (Surabaya: Genta Publishing, 2006), h. 191 


\section{Tahkím}

Vol. XIV, No. 1, Juni 2018

Dengan demikian dapat diasumsikan bahwa pemikiran hukum progresif lebih mengarahkan pada kebebasan pelaku hukum untuk menentukan intuisi hukum itu sendiri manusia sebagai peletak dasar atas kepastian hukum, bukan sebagai pengabdi pada hukum itu sendiri. Jadi, aplikasi hukum tertulis yang merupakan rangkaian konsep hukum positif yang menghendaki adanya kedudukan peraturan perundang- undangan sebagai langkah kepastian hukum dipandang tidaklah sejalan dengan konsep budaya bangsa Indonesia yang berbhineka dalam keragaman kultural yang tersebar di wilayah nusantara ini. Sehingga wujud dari hukum progresif dipandang lebih sejalan dengan budaya bangsa Indonesia, terkhususnya di wilayah timur Indonesia yang masih memiliki keragaman kultural, dimana kedudukan kebudayaan masyarakat yang merupakan kerangka adat istiadat suatu masyarakat merupakan intuisi hukum yang terus terpelihara, diyakini dan dihormati.

Interprestasi hukum progresif yang lebih mengedepankan perkembangan hukum berdasarkan intuisi masyarakat dapat ditafsirkan pada keinginan masyarakat dalam memilih otonomi desa berdasarkan unsur keyakinan masyarakat itu sendiri secara kolektif dan menurut pranata sosial masyarakat di kawasan timur Indonesia, intuisi hukum adat dipandang sebagai pranata hukum yang dihormati diakui dan diyakini keadilan serta kepastian hukumnya yang diperkuat dengan hukum nasional

Karena itu interprestasi hukum adat dalam sistem pemerintahan di negeri Batu Merah dapat dipandang sebagai sarana pembangkit pemerintahan melalui otonomi desa dengan kemandiriannya dalam mengelola sumber daya yang ada di desa tersebut dan hal ini dipandang sejalan dengan paradigma hukum progresif.

Intensitas progresifitas hukum, memiliki makna yang sejalan dengan konsep budaya hukum yang mengandung makna proses internalisasi nilai - nilai yang hidup dan berkembang dalam masyarakat yang dapat dijadikan sebagai landasan dalam pemahaman dan penegakan hukum. Dalam kaitan ini menurut Daniel S. Lev, bahwa budaya hukum dapat dibedakan menjadi dua bagian, yang pertama adalah budaya hukum prosedural, yang terkait dengan nilai-nilai yang hidup dalam masyarakat dalam menyelesaikan permasalahan dalam sistem pemerintahan negeri. Sedangkan budaya hukum yang kedua; budaya hukum substantif, terkait dengan asumsi-asumsi fundamental terutama mengenai apa yang adil dan tidak menurut masyarakat. ${ }^{25}$

Sejalan dengan hal tersebut, L. Friedman, juga membedakan budaya hukum menjadi dua bagian, yaitu internal legal culture, yaitu kultur yang dimiliki oleh struktur hukum dan external culture, yakni kultur hukum masyarakat pada umumnya, budaya hukum terkait dengan ide-ide, sikap, harapan, pendapat dan nilai-nilai yang berhubungan dengan hukum bisa positif ataupun negatife. ${ }^{26}$ Dengan demikian, dapat

${ }^{25}$ Daniel S. Lev, dalam Ahmad Lonthor, Pengaturan Terhadap Eksploitasi Sumber Daya Laut di Maluku Tenggara, Tinjuan Sosiologis Hukum Adat dan Hukum Nasional, (Disertasi) (Makassar: Program Pasca Sarjana Universitas Hasanudin Makassar, 2014), h. 47

${ }^{26}$ Ibid., h. 51 


\section{Tahkím}

Vol. XIV, No. 1, Juni 2018

dikatakan, bahwa budaya hukum merupakan proses internalisasi nilai- nilai positif untuk dijadikan sebagai landasan yang kuat atau kokoh dalam rangka memahami hukum secara baik dan benar untuk diimplementasikan dalam interaksi atau pergaulan masyarakat.

Eksitensi hukum adat dalam penyelenggaraan pemerintahan di negeri Batu Merah dalam membangun dan mengelola sumber daya yang ada di negeri Batu Merah itu sendiri masih tetap eksis. Hal ini bertujuan untuk membangun masyarakat yang mandiri, masyarakat yang sejahtera melalui amanah Undang-undang Nomor 6 tahun 2014 tentang Desa. Dalam Teori Lawrance Friedman dijelaskan bahwa sistem hukum terdiri dari sub-sub sistem yang saling berintegrasi antara sub yang satu dengan yang lain. Sub tersebut adalah substansi yaitu pola yang memperlihatkan bagaimana suatu institusi hukum bekerja dengan suatu bentuk yang tetap, kerangka kelembagaan dari sistem, struktur adalah peraturan-peraturan yang terdiri dari peraturan primer (norma tingkah laku) dan peraturan sekunder (yang mengatur bagaimana norma-norma pokok dilaksanakan dan budaya hukum yang merupakan sikap-sikap yang terpola, nilai-nilai, prinsip-prinsip, gagasan yang terstruktur sedemikian rupa sehingga yang dianut baik oleh setiap individu maupun kelompok dalam masyarakat. ${ }^{27}$

Dalam pemerintahan di negeri Batu Merah, terdapat struktur organisasi yang formal dan sumber daya manusia yang cukup untuk mengelola sumberdaya alam yang terkandung di dalamnya. Struktur lembaga adat tidak berdiri sendiri melainkan menyatu dan berada dalam struktur pemerintahan adat/negeri. Secara umum terbagi atas empat lembaga, ${ }^{28}$ yaitu :

a. Raja atau Pemerintah sebagai kepala atau pimpinan masyarakat hukum adat.

b. Saniri Raja Pattih yaitu lembaga adat yang melaksanakan pemerintahan negeri sehari-hari terdiri dari raja dan Kepala Soa, selain menjalankan pemerintahan, lembaga ini berfungsi sebagai hakim perdamaian/hakim adat sehingga disebut Makemat Raja Patti.

c. Saniri Negeri (Saniri Lengkap) berfungsi sebagai lembaga legislatif, yang bertugas memusyawarahkan masalah menyangkut kepentingan negeri seperti masalah pembangunan, pemberdayaan, pengembangan dan pengelolaan sumberdaya alam, kemudian memilih dan melantik Pemerintah berdasarkan tata cara adat negeri tersebut, memberikan kebijaksanaan dan mengeluarkan peraturan-peraturan negeri, terdiri atas: Raja, Saniri Raja Pattih, tua-tua adat negeri, Kewang, petugas-petugas dibidang keagamaan atau mereka yang

\footnotetext{
${ }^{27}$ Lastuti Abubakar, "Revitalisasi Hukum Adat, Sebagai Sumber Hukum dalam Mmembangun Sistem Hukum Indonesia,” Jurnal Hukum, Universitas Padjajaran Bandung, 2011, hlm. 6

${ }^{28}$ Sakinah Safarinah Putuhena, Kewenangan Lembaga Adat Dalam Penyelesian Sengketa Pada Masyarakat Hukum Adat Maluku Tengah, Jurnal Fakultas Hukum Univerasitas Hasanudin Makassar, 2008, h. 8
} 


\section{Tabkím}

Vol. XIV, No. 1, Juni 2018

diangkat menurut adat dan dipilih sebagai wakil dari rakyat biasa sebagaimana di amanahkan dalam undang-undang.

d. Saniri Besar, merupakan forum rapat terbuka antara saniri negeri dengan seluruh penduduk yang bersidang setahun sekali di baleo negeri dan biasanya dilaksanakan di awal tahun. Dalam pertemuan ini pemerintah negeri yang diwakili oleh pamerentah/raja menyampaikan pertanggung jawaban berkenan dengan jalannya pemerintahan dan keuangan negeri serta hal-hal lain yang menyangkut negeri pada tahun sebelumnya. Rapat Saniri besar ini juga dipimpin oleh raja.

Van Vollenhoven dalam pembidangan hukum adat yang tidak memisahkan antara pemerintahan dan adat istiadat. Sehingga dalam masyarakat hukum adat pemerintahan negeri dan lembaga adat berada dalam struktur yang sama. Hukum adat yang hingga saat ini masih hidup dan berlaku dalam masyarakat hukum adat Maluku khususnya Negeri Batu Merah yang dikenal dengan hukum Sasi maupun sumpah adat. Hukum Sasi adalah hukum adat yang berkaitan dengan larangan untuk mengambil, baik hasil hutan atau hasil laut dalam jangka waktu tertentu yang ditetapkan oleh pemerintah setempat.

Hukum Sasi telah menjadi bagian dari cara hidup orang Maluku. Ketika cengkeh, pala, kelapa mulai berbunga atau hasil-hasil laut mulai muncul, pemerintah negeri dengan segenap perangkatnya merasa perlu melindungi hasil-hasil darat dan laut tersebut, dengan mengumumkan pelaksanaan sasi. Tujuannya agar tidak diambil sampai dengan saatnya hasil-hasil tersebut bisa dipanen sehingga kualitas hasil-hasil bumi dan laut tersebut secara ekonomis bisa produktif. Tradisi ini selain dimaksudkan untuk memelihara lingkungan alam, juga sebagai bentuk atau cara orang Maluku dalam memelihara produktivitas hasil-hasil pertanian dan kelautan lainnya. Sasi juga merupakan tindakan perlindungan bagi kelanjutan perekonomian dan ekosistem mahkluk hidup di laut dan di darat bisa berlangsung secara wajar, sehingga kerusakan terhadap lingkungan tidak akan terjadi atau berkurang. Dalam perkembangan selanjutnya saat ini tidak semua negeri menerapkan hukum Sasi. Seperti yang terjadi negeri Hitu hal tersebut diakibatkan perkembangan penduduk yang menyebabkan berubahnya hutan dan dusun menjadi lahan pemukiman dan perkembangan ekonomi yaitu perubahan mata pencaharian masyarakat yang sebagian besar adalah pegawai dan pedagang. $^{29}$

Dalam penegakan pemerintahan yang bersih menuju otonomi desa yang lebih mandiri dalam pengembangan sumber daya manusia yang lebih baik, maka pada dasarnya raja, sekretaris, bendahara, kepala soa, maupun yang termasuk dalam struktur pemerintah negeri Batu Merah dapat menjalankan peran yang mendidik, pemberdayaan

\footnotetext{
${ }^{29}$ J. Sahalessy, "Peran Latupati Sebagai Lembaga Hukum Adat Dalam Penyelesian Konflik Antar Negeri di Kecamatan Leihitu Provinsi Maluku,” Jurnal Sasi, Vol. 17, 2011, h. 8
} 


\section{Tahkím}

Vol. XIV, No. 1, Juni 2018

masyarakat, penegakan hukum yang didasarkan pada prinsip bahwa adanya hukum itu bukan untuk dilanggar melainkan untuk ditaati dan di sadari. Kemudian penjatuhan sanksi kepada si pelanggar hokum juga bukanlah dimaksudkan untuk menghukumnya, melainkan sebagai upaya membuat ia merasa malu dan untuk mempengaruhi masyarakat lainnya agar menyadari bahwa melakukan perbuatan melanggar hukum tersebut merupakan "keberatan batin." Penerapan sanksi pada prinsipnya dilakukan di muka umum dengan maksud untuk menekan masyarakat lainnya supaya tidak ikut melakukan perbuatan melanggar hukum. ${ }^{30}$ Dengan demikian menjadi alat edukasi dalam membangun kesadaran hukum bagi masyarakat.

\section{Otonomi Desa Pasca Undang-Undang Desa}

Otonomi desa harus menjadi inti dari konsep NKRI. Jelasnya, bahwa 'otonomi desa' bukan merupakan cabang dari otonomi daerah. Karena yang memberi inspirasi adanya otonomi daerah yang khas bagi NKRI adalah otonomi desa. Otonomi desa harus menjadi pijakan dalam pembagian struktur ketatanegaraan Indonesia mulai dari pusat sampai ke daerah yang kemudian bermuara pada regulasi otonomi desa yang tetap berpedoman pada keaslian "'desa' sebagai kesatuan masyarakat hukum.

Perlindungan konstitusi terhadap otonomi desa, secara implisit juga di atur dalam pasal 281 UUD 1945, yang menegaskan bahwa "identitas budaya dan hak masyarakat tradisional di hormati selaras denga perkembangan zaman dan peradaban." Pengertian tentang kewenangan sesuatu daerah hokum yang dilukiskan dengan istilah "otonomi" dalam bahasa Indonesia, hak untuk mengatur dan mengurus 'rumah tangga' sendiri.

Menurut Soertadjo kartohadikoesoemo, dalam hukum adat sebenarnya tidak dikenal oleh bangsa Indonesia. Pengertian tentang otonomi desa itu adalah ciptaan bangsa Belanda, waktu mereka masih memegang kekuasaan di Indonesia. Dalam pengertian otonomi menurut tradisi hukum tata negara asing itu, desa di Indonesia sebagai daerah hukum yang paling tua menjalankan otonomi sangat luas, lebih luas dari otonomi daerah-daerah hokum di atasnya yang menyusul di kemudian hari, baik yang dibentuk oleh desa-desabersama-sama dengan sukarela, maupun yang di paksakan oleh pihak-pihak yang lebih kuat. Oleh daerah-daerah hukum yang lebih tinggi itu kemudian otonomi desa mendapat pembatasan-pembatasan tertentu.

Kajian hukum terhadap otonomi desa biasanya berkaitan dengan bagaimana negara 'memperlakukan'” desa. Dilihat dari makna pengaturan sebagaimana tercantum dalam pasal 18 UUD 1945 berikut penjelasannya, dapat dikatakan bahwa esensi dari pasal tersebut mencerminkan pengakuan Negara terhadap 'otonomi desa' dewasa ini.Lebih dari itu,dengan menyebut desa sebagai "susunan asli yang memiliki hak asal-usul" maka menurut UUD 1945 hanya desa yang dipastikan memiliki otonomi. Ketika terjadi reformasi ditahun 1998,pengaturan tentang desa lebih demokratis

\footnotetext{
${ }^{30}$ Astiti Dalam Sakinah Safarinah Putuhena, op.cit., h. 8
} 


\section{Tahkím}

Vol. XIV, No. 1, Juni 2018

dibanding masa Orde Baru muncul melalui UU No 22 tahun 1999 tentang Pemerintahan Desa.Salah satu perubahan mendasar dalam pengaturan mengenai desa adalah munculnya Badan Perwakilan Desa (PBD yang merupakan lembaga yang memiliki fungsi yang sangat luas seperti mengayomi adat istiadat, membuat peraturan desa, menampung dan menyalurkan aspirasi masyarakat serta melakukan pengawasan terhadap penyelenggaraan pemerinta desa. Ketua BPD tidak di rangkap oleh kepala oleh desa sebagaimana di atur dalam UU No.5 tahun 1979, tetapi dipilih dari anggota BPD sendiri.

Dalam pandangan Ari Dwipayana, rumusan yang pada awalnya memberikan janji keleluasaan desa dalam berkreasi menyusun kebijakan desa sesuai dengan adat istiadat setempat menjadi ragu dalam pelaksanaaan, karena UU No.22 tahun 1999 masih setengah hati dalam memberikan pengakuan otonomi desa. Penyembutan bahwa desa memiliki otonomi asli justru termuat di bagaian penjelasan,bukan dalam batang tubuh UU tersebut. Apalagi setelah ada perubahan UUD 1945, justru pengakuan bahwa desa memiliki otonomi asli tidak muncul secara tegas dalam pasal 18 ayat 1 maupun dalam pasal $18 \mathrm{~B}$ ayat 2 . Apabila ketentuan pasal 18 ayat 1 dihubungkan dengan pasal 18B ayat 2 dapat di pahami bahwa keberadaan masyarakat adat di akui secara konstitusional, namun eksistensi daerah-daerah yang mempunyai susunan asli yang di huni masyarakat adat tidak mendapat jaminan.Tegasnya subyeknya diakui namun daerah tempat tinggalnya tidak mendapatkan pengakuan. Pasal 18 ayat 1 UUD 1945 hanya membagi wilayah Negara atas daerah-daerah provinsi dan daerah provinsiprovinsi dibagi atas daerah kabupaten/kota yang dikelola menurut asas otonomi.Lebih jauh tentang masyarakat adat dalam pasal ini tidak ditemukan penjelaannya.

Unsur-unsur otonomi desa yang penting antara lain : 1) Adat tertentu yang mengikat dan ditaati oleh masyarakat di desa yang bersangkutan; 2) Tanah, pusaka,dan kekayaan desa; 3) Sumber-sumber pendapatan desa; 4) Urusan rumah tangga desa; 5) Pemerintah desa yang dipilih oleh dan dari kalangan masyarakat desa yang bersangkutan,yang sebagai alat desa memegang fungsi "mengurus"; 6) Lembaga atau badan "perwakilan" atau musyawarah,yang sepanjang penyelenggaraan urusan rumah tangga desa memegang fungsi "'mengatur."

Dalam perjalanan sejarah bisa terjadi dan memang ada yang terjadi,perubahanperubahan bobot otonomi desa sedemikian rupa,sehingga pada suatu waktu bisa diketemukan satuan-satuan masyarakat yang tidak lagi memenuhi seluruh atau sebagian unsur-unsur otonomi desa, atau dengan perkataan lain,seluruh atau sebagian hak-hak dan kewenangannya sebagai masyarakat hokum adat tidak berfungsi lagi.Pada umumnya hal itu terjadi antara lain apabila:

1. Penduduk desa semakin heterogen sehingga sukar ditentukan,hokum adat mana yang dapat berlaku didalam masyarakat yang bersangkutan. 


\section{Tahkím}

Vol. XIV, No. 1, Juni 2018

2. Aspek-aspek kehidupan masyarakat yang selama ini (cukup) diselenggarakan oleh desa, oleh satu dan lain alasan berdasarkan ketentuan yang lebih tinggi, diselenggarakan oleh pemerintah yang lebih atas.

3. Kegiatan ekonomi sekunder dan tersier semakin besar,sehingga diperlukan penataan kembali terhadap tata ruang fisik dan tata masyarakat desa yang bersangkutan menurut norma-norma yang lebih tinggi.

4. Sumber-sumber pendapatan desa "diambil alih" oleh pemerintah yang lebih atas.

Relevan dengan hal itu Sutoro Eko mengatakan, bahwa perwujudan ide otonomi desa, maupun kedudukan dan kewengan desa,tentu membutuhkan kebijakan desentralisasi dan subsidiariti. Prinsip dasar pertama desentralisasi desa adalah pengakuan dan penghormatan terhadap keberadaan desa yang beragam,meski solusi tentang kedudukan dan kewenangan desa bisa beragam juga.Pengakuan ini secara minimal berarti mengukuhkan desa sebagai self-governing-community atau kesatuan masyarakat hukum. Pada level yang lebih tinggi, desentralisasi desa berupaya membentuk desa sebagai local-self-government atau "otonomi desa' seperti halnya "otonomi daerah" yang memiliki provinsi dan kabupaten/kota. Otonom desa yang dikukuhkan atau desa sebagai local-self-government itu lebih dari sekedar status "otonomi asli" yang sudah lama dimiliki desa sebagai self-governing-community. Dengan demikian desa mempunyai kedudukan dan kewenangan yang jelas dalam struktur ketatanegaraan yang ditegaskan dalam peraturan perundang-undangan, sekaligus memiliki keleluasan, kekebalan dan kemampuan untuk mengelola rumah tangganya sendiri secara otonom.

Dalam konteks kelembagaan desa, tampaknya agenda demokratisasi, otonomi, dan desentralisasi merupakan faktor kunci yang penting agar dapat mengevektifkan peran dan fungsinya. Desentralisasi diperlukan sebagai bentuk pemgakuan Negara terhadap self-governing-community. Dalam desentralisasi desa, dimungkinkan adanya pembagian kewenangan serta keuangan kepada desa/gampong untuk mambuat desa bermakna local-self-government. Jika desentralisasi ditujukan untuk penataan kelembagaan model baru yang menggabungkan antara desa (local-self-government) dan adat (self-governing-community), maka hasilnya adalah (1) penataan kelembagaan desa yang sesuai dengam adat dan kebijakan Negara; (2) model loal self government desa tetap mendasarkan pada prinsip self-governing-community, bahkan memiliki basis kultural dan social yang kuat; (3) terdapatnya batas-batas wilayah dan hak ulayat desa secara jelas; (4) pemulihan identitas local dan modal sosial; dan (5) pengalihan kewengan dan keuangan pada desa baru.

Olehnya itu kemandirian desa ketika di beri wewenang penuh untuk mengelola rumah tangganya sendiri menjadi salah satu hal yang baru dan sangat bermakna positif bagi masyarakat negeri Batu Merah dengan diundangkan Undang-undang Nomor 6 tahun 2014 tentang Desa. Otonomi desa inilah yang ditunggu-tunggu oleh masyarakat 


\section{Tahkím}

Vol. XIV, No. 1, Juni 2018

untuk membangkitkan tingkat perekonomian dalam masyarakat negeri Batu Merah, pemberdayaan secara penuh kepada masyarakat Batu Merah dengan beragam kegiatan yang bertujuan untuk kesejahteraan masyarakat.

Dengan demikian kedudukan Undang-undang Nomor 6 tahun 2014 jika dikorelasikan dengan hukum progresif yang cenderung mengedepankan cita-cita hukum untuk manusia, maka relevansi animo masyarakat negeri Batu Merah yang menginginkan kemandirian dalam mengurusi otonomi desa mereka sendiri sebagaimana yang telah di amanahkan oleh undang-undang pada prinsipnya menggunakan pendekatan hukum progresif adalah sejalan dengan cita budaya hukum adat isti adat masyarakat negeri Batu Merah yang menekankan nilai - nilai yang hidup di dalam masyarakat.

\section{Kesimpulan}

Berdasarkan uraian yang dijelaskan di atas dapat disimpulkan bahwa:

1. Otonomi desa dan kesejahteraan masyarakat negeri Batu Merah sangat bermakna positif dalam mengatur dan mengurus 'rumah tangga' sendiri oleh masyarakat negeri Batu Merah. Hal ini dilaksanakan dengan kewenangan yang diberikan dalam undang-undang desa terhadap penyelenggaraan pemerintahannya yang bersih dan terbuka demi kesejahtraan dalam masyarakat.

2. Pandangan hukum progresif terhadap otonomi desa dan kesejahteraan masyarakat negeri Batu Merah dalam kedudukan Undang-Undang Nomor 6 tahun 2014 tentang Desa jika dikorelasikan, maka cenderung mengedepankan cita-cita hukum untuk manusia. Relevansi animo masyarakat negeri Batu Merah yang menginginkan kemandirian dalam mengurusi otonomi desa mereka sendiri yang telah diamanahkan oleh undang-undang pada prinsipnya menggunakan pendekatan hukum progresif adalah sejalan dengan cita budaya hukum indonenesia yang menekankan nilai-nilai yang hidup di dalam masyarakat.

\section{DAFTAR PUSTAKA}

Abubakar, Lastuti. "Revitalisasi Hukum Adat, Sebagai Sumber Hukum Dalam membangun Sistem Hukum Indonesia," Jurnal Hukum, Universitas Padjajaran Bandung, 2011,

Ali, Achmad. Menguak Teori Hukum Dan Teori Peradilan, Jakarta: Kencana, 2009.

Fajar, Mukti. Dualisme Penelitian Hukum Normatif dan Empiris, Yogyakarta: Pustaka Pelajar, 2010.

Badan Pusat Statistik Kota Ambon, Potret Usaha Pertanian Hasil Sensus Pertanian Desa Batu Merah Tahun 2016.

Kiat, M. Saleh. Pejabat Negeri Batu Merah "wawancara”, di Kantor Pemerintah Negeri Batu Merah pada tanggal 20 Juli, 2016. 


\section{Tahbím}

Vol. XIV, No. 1, Juni 2018

Kusuma, Mahmud. Menyelami Semangat Hukum Progresif, Terapi Paradigmatik Bagi Lemahnya Penegakan Hukum Indonesia, Yogyakarta: Antony Lib-Indonesia, 2009.

Leurima, Ida. Sekretaris Pengurus Pemerintahan Desa/Negeri di Negeri Batu Merah Kecamatan Sirimau Kota Ambon, Tanggal 25 Agustus 2016

Lonthor, Ahmad. Pengaturan Terhadap Eksploitasi Sumber Daya Laut di Maluku Tenggara, Tinjuan Sosiologis Hukum Adat dan Hukum Nasional, dalam (Disertasi), Makassar: Program Pasca Sarjana Universitas Hasanudin Makassar, 2014.

Al-Muhtar, Zain. Teori Hukum Progresif Menurut Satjipto Rahardjo, dalam http://sergie-zainovsky.blogspot.com/2012/10/teori-hukum-progresif-

menurut-satjipto.html, pg. 2 diakses pada Agustus 2014.

Putuhena, Sakinah Safarinah. "Kewenangan Lembaga Adat Dalam Penyelesian Sengketa Pada Masyarakat Hukum Adat Maluku Tengah," Jurnal Fakultas Hukum Univerasitas Hasanudin Makassar, 2008.

Ralahalu, Karel Albert. Otonomi Daerah Di Tengah Konflik Merancang Succes Story Implementasi Otonomi Daerah Di Provinsi Maluku, Suatu Pengantar Menteri Dalam Negeri H. Moh. Ma'ruf, Cet II, 2012.

Sahalessy, J. "Peran Latupati Sebagai Lembaga Hukum Adat Dalam Penyelesian Konflik Antar Negeri di Kecamatan Leihitu Provinsi Maluku," Jurnal Sasi, Vol. 17, 2011,

Soehino, H. Hukum Tata Negara, Sejarah Ketatanegaraan Indonesia Menjelang Dan Pasca Di Lakukan Perubahan Pertama, Perubahan Kedua, Perubahan ketiga Dan Prubahan Keempat Undang-Undang Dasar Negara Republik Indonesia Tahun 1945, Yogyakarta: BPFE, 2005.

Soemantri, HRT. Sri. Hukum Tatanegara Indonesia Pemikiran Dan Pandangan, Cet I, Bandung: PT Remaja Rosdakarya, 2014.

Sukriono, Didik, M. Syaiful Aris, Umbu Pariangu., Otonomi Desa Dan Kesejatraan Rakyat, Malang: Intras Institute, 2014.

Suratman, dkk. Metode Penelitian Hukum, Bandung: Alfabeta, 2013

Tanya, Bernard L., Yoan N. Simanjuntak, Markus Y. Hage. Teori Hukum Strategi Tertib Manusia Lintas Ruang Dan Generasi, Surabaya: Genta Publishing, 2006 .

Kantor Desa Negeri Batu Merah "Observasi" Struktur Organisasi Pengurus Pemerintahan Desa/Negeri di Negeri Batu Merah Kecamatan Sirimau Kota Ambon, Tanggal 20 Agustus 2016

Rancangan Pembangunan Jangka Menengah (RPJMDes Dan REKPDES) Negeri Batu Merah Kecamatan Sirimau Kota Ambon Provinsi Maluku Tahun 2015-2020 


\section{Tahbím}

Vol. XIV, No. 1, Juni 2018

Rancangan Pembangunan Jangka Menengah (RPJMDes Dan REKPDES) Negeri Batu Merah Kecamatan Sirimau Kota Ambon Tahun 2015-2020.

Republik Indonesia, Undang-Undang Dasar Negara Republik Indonesia Tahun 1945 Republik Indonesia. Undang-Undang Nomor 6 Tahun 2014 Tentang Desa

Yuliantoro \& M. Damayanti. "Is Economic Viability The Answer For Community's American Qol Assessment,?" Jurnal Tataloka, Vol. 10, No. 1,2008. 